\title{
Preface
}

When I started to write this book, my aim was to show how an average, conventional, middle-class woman became involved and active in the peace and women's movements. I would like to tell a story that can show how anyone in circumstances similar (or perhaps not so similar) to mine can make contributions to change which will eventually lead, we hope, to better lives for the people we live and work with and for many others around the world. It would be satisfying if it were possible for some women to say, 'Well for goodness' sake, if she could do it, I don't see why I couldn't.' Or, 'That doesn't seem so difficult; perhaps I could ...' Or even, 'If that's the kind of mess they made, we can certainly do better this time.'

People I've spoken to all have different expectations of this book. Some want a psychological portrait of what prompted me to do things, to join particular organizations, and so on. Others want a minutely detailed history of the women's movement, with analyses of who did what right and who did what wrong at specific times. But I'm not a historian. I've written down my version of things as I remember them, and my memory, like everyone else's, is only semi-perfect.

Most, if not all, of the women I've talked to feel that the part which appeals to them most is how the personal gets involved with the political and how one develops from the other. And how it is possible to lead an ordinary life while at the same time adding some little bit to what is affecting the course of our history. And how individuals have felt about some of the historical events and attitudes of people over those times.

None of us is born determined to head a national organization working for change or knowing Robert's Rules by heart, let alone possessed of a feminist critique showing why consensus-based decision- 


\section{viii Preface}

making is superior. I wasn't born a radical; it was a step-by-step process. I was given many opportunities for learning, mostly when someone asked me to do something and suggested ways in which it might be done. The best way to learn is by doing. Almost everything I believe in and have worked for has been learned from others - by example, by teaching, or by some kind of osmosis. All I can do is thank my teachers and hope I can pass on some of the ideals and inspiration they have given me.

No one takes on the project of changing the world by next week, so writing about all these years of women's activities is rather like trying to document the actions of a swarm of bees or a nest of ants. All kinds of things are going on, and some look aimless or inconsequential, yet they all have a purpose. When you take them all together, you see the building and achieving of the aims of a community.

I think much of this coherence is achieved largely by intuition. To some extent one looks at what others are doing and sees what one thinks needs adding. Often you do what you feel comfortable doing, according to a set of principles and feelings you might never make explicit. Some ways of doing things are instinctively comfortable, such as the more egalitarian structure of women's groups. And some things, of course, one knows about. For instance, I always hated and feared being physically hurt or knowing that others were being hurt. Wanting to avoid pain and suffering led to the conviction that violence, oppression, and war are unacceptable. I don't think I understood mental distress and pain as easily, and I've never been very good at recognizing this in others or even in myself. This is where my education owes much to my friends and family. Learning never stops.

I hope this story will contain enough material to show that life can be fun and exciting. Working to change things, to 'save the world,' doesn't have to be pompous or dull or all those other things that don't appeal. Certainly one can combine serious work and involvement in one's community with pleasure and enjoyment.

In many ways, I seem to have been taking things for granted. I've been elected president of three quite significant women's organizations: AWE, the Association of Women Electors; VOW, the Voice of Women; and NAC, the National Action Committee on the Status of Women. I've been fortunate enough to have, or to be able to raise, enough money to get to all sorts of fantastic meetings and occasions which were often historic. At one Voice of Women meeting in the 1980s, I counted eight Persons Award winners who were also VOW members. 
I've never missed the annual general meetings of VOW and only one NAC AGM (when I was in hospital). When I add up those meetings alone - thirty years of VOW and eighteen years of NAC - my mind is boggled by the travel, the money, the words, and all the wonderful women I have met, and stayed with, at these gatherings. Everywhere there was something new to learn, about how women do things, how they think, and what makes them tick.

I have NAC and VOW to thank for my love affair with Newfoundland and for my obsession with British Columbia. The Prairies, the Maritimes, and the Territories have given me magnificent friends and exciting experiences, and without VOW and NAC I would not have known such great Quebec women. Women, dozens of them, have stayed with me too, and often I remember what they gave me: a doll, a piece of wood, a button, a jade brooch, a scented geranium, how to peel garlic (hit it), how to finger-weave, political know-how, how to park a car with a trailer, how to light a fire or stop draughts, and recipes, and on and on. I also mourn all the information and history I have forgotten.

I was lucky enough to have a long-suffering family who never prevented or opposed any of my exploits and of whom I am inordinately proud. I bask in the reflected light of my husband's monumental academic achievements, my son's mechanical, mathematical, and musical talents, my daughters' dancing, artistic, teaching, and intellectual abilities - but most of all their love. I got affection and warmth from all of them, more than I deserve, and from all of them an education that goes on whenever we are together.

But I'm not an exceptional person. I can't understand what Kay Macpherson has that most of my friends haven't got too. I don't know what got me the Order of Canada, except for Elsie MacGill's efforts. I'm not indulging in false modesty here. I know I'll have to keep trying to be less lazy, exploitative, unaffectionate, and so on. And thanks to all those who obviously partly disagree with my assessment. I do love you - even if I find it so hard to say so.

WRITING THIS BOOK

The writing of this book probably began in 1941 when I bought a portable Hermes typewriter from a Swiss skiing friend in Montreal. My first piece began, 'In order to practise my typing ...' My first typing lesson was given to me for one penny by a fellow student at St Thomas' Hospital in London, but I never did progress to proper touch-typing. 


\section{$x$ Preface}

From then on, I often wrote pieces, at first as a form of diary-keeping, then later also by way of recording events that seemed to me significant or drawing pen portraits of my friends. The pieces I wrote in New Brunswick went into a file and lay dormant for about forty years. Then I wrote mostly reports, letters, and oddments like doggerel, notes for speeches, and a sort of diary (more a date book really).

In the early 1980s, I began creative writing classes and wrote viewpoint pieces, portraits of family events, my friends, and so on. My children wanted to know about their family origins, so that turned into quite a long account. Then people were always asking for short histories of AWE, VOW, NAC, and so on, so I started to think seriously about making my writings into a book.

As my eyesight worsened and it became more difficult for me to read, especially my own writing, I needed to look for help. Thanks to Naomi Black, who applied on my behalf, I received a grant from the Social Sciences and Humanities Research Council (SSHRC) which enabled me to recruit student helpers who came to sort, read, and make suggestions, decipher illegible handwritten notes, type, and retype. They include Marie Hammond, Rachel Gray, Wendy Miller, Les Tager, Linda Potje, Liz Fitting, Michael Mackid, Todd Waring, Loretta Castelaria, and Audrey Hepworth.

I then received a grant from the Explorations Program of the Canada Council, which I'm sure I wouldn't have got without glowing references from Margaret Fulton, Alison Prentice, and Ursula Franklin. This enabled me to employ an editor, Christine Donald, who worked with me for nearly three years in a process she describes as 'very like quilting.' We enjoyed each other's company and worked amicably through changes and rewrites. I had not worked with an editor before and did not realize how much was involved. I cannot sufficiently appreciate the gold-mine of professional expertise Christine provided. I grew to admire her editorial talents more and more, particularly her ability to condense incidents or comments without losing their essential elements. She deserves all my thanks wrapped up in a big bear-hug.

Friends heroically read parts of the manuscript and many helpful comments were provided by Ursula Franklin, Rosemary Brown, Naomi Black, Ann Gertler, Sue Findlay, Vi Thompson and Miriam May, Muriel Duckworth, Anna Lou Paul, Marie Crookston, Mary Louise Gaby, Sheila Macpherson and Bill Smith, Susan Macpherson, Danny Grossman, Stanley Ryerson, Herbert Whittaker, Sarah Henderson, Alice de Wolfe, Dorothy Smieciuch, and, last but not least, June Callwood. They 
gave all kinds of advice, most of which I tried to follow (my motto being, 'When in doubt, do both'). I owe special thanks to Isobel Warren, who advised on the photographs and their layout.

And all along I would have been lost without the devoted help of Pearl Blazer. In addition to the skills and abilities I knew from her time with NAC, she mastered a computer, made scraps of scribbled writing into usable prose, trimmed my inordinate flights of fancy, plugged the gaps in my memory, argued about my illogical assumptions, and generally set me straight. Her ever-increasing job description includes strange non-secretarial activities such as medical opinions, sewing, finance, cooking and cleaning, and car-driving. She has put up with the fumblings and frustration of one who is losing her sight. I cannot put into spoken words what her support and love have meant to me. I can only write, 'Thanks, Pearl, and bless you!'

Now I have a completed manuscript, the publishing of which has been made possible by a grant from the Three Guineas Charitable Foundation. I owe much to the efforts of my friends and helpers and have not been able to name them all here, but to all the people who helped me get to this point, my thanks.

\section{Toronto}

December 1990 
